Amir Mohammad Gamini. Dāyirihā-yi Mīnā-ī: Pajūhash-ī dar Tārikh-i Kayhān Shināsī dar Tamaddun-i Istāmī [Enamel Circles: A Survey of the History of Cosmology in Islamic Civilization]. Tehran: Nashr-i Sīnā, 1395/2016. 364 pages. ISBN: 9786008058014.

\title{
Kaveh Niazi*
}

Amir Gamini's Enamel Circles, published in Persian, is a thorough and scholarly treatment of an important episode in the history of the physical sciences, namely, the development of theoretical astronomy in the Islamic world. Known as hay'a to its practitioners, this term signifies "configuration" in Arabic and denotes the arrangement of the universe's various parts in their pre-modern and largely Aristotelian form. Among the topics it included were the location and arrangement of Earth and the mundane elements residing below the Moon's orb, as well as the intricate machinery of the heavenly orbs themselves. Standard texts (written primarily in Arabic, but also in Persian) began with a discussion of the spherical shape of Earth, which was envisioned as solid and located at the center of God's creation, as well as its successive encasement in orbs of water, air, and fire. Presented next was the configuration of the heavens - including formulations for the size and location of the various celestial orbs that, ceaselessly spinning, carried the firmament and the stars, together with the planetary bodies (i.e., the Sun, the Moon, Mercury, Venus, Mars, Jupiter and Saturn) all along their nightly paths.

Springing from Ptolemy's (d. ca. 170) seminal text The Almagest, as well as his shorter and subsequently penned Planetary Hypotheses, hay'a represents the fruits of a centuries-long research project in which the scientists of the Islamic world engaged with, modified, and developed this classical Greek scientific heritage. The hay'a tradition was subsequently transmitted to early modern Europe, as can be seen in the planetary models of Nicolas Copernicus (d. 1543). An adroit examination of this tradition's history through the planetary models of its most well-known practitioners, Enamel Circles thus illuminates a scientific tradition

Dr., Stanford Online High School, Stanford, California. 
that was both central to the scientific activity within the Islamic world and crucial to the modern world's development.

Enamel Circles is based, in part, upon Gamini's doctoral dissertation on Quțb alDīn Shīrāzì (d. 710/1311), "Shīrāzī and his role in the science of hay'a."1 Completed at Tehran's Iranian Institute for Philosophy in 2013, it received several awards as well as recognition from the International Union of History and Philosophy of Science and Technology (IUHPST). Included in this dissertation was a detailed look at Shīrāzī's planetary models and that of other researcher's in the hay'a field. The present work, which is a more concise yet compelling refashioning of this material within the context of the history of science as a whole, is divided into an introduction and three sections: "Cosmology in Greece and the Islamic world," "A Cosmology Consonant with Natural Philosophy," and "The Scientific Legacy of the Maragha Astronomers," respectively. Gracing the work is a foreword by Hossein Massoumi Hamadani, who served as Gamini's Ph.D. adviser in Tehran.

In his study, which spans the beginnings of hay'a to its encounter with modern astronomy in eighteenth-century Europe, Gamini focuses on several key scientists, among them Ibn al-Haytham (d. ca. 432/1040), Mu'ayyad al-Dìn al-'Urḍi (d. 664/1266), Nașīr al-Dīn Ṭūsī (d. 672/1274), and Shīrāzì. It is worth noting that all of them, except Ibn al-Haytham, were associated at some point in their careers with Persia's renowned Maragha observatory, a fact that privileges the period during which these "Maragha School" astronomers were active. Gamini justifies this scheme by pointing out that the subsequent evolution of theoretical astronomy depended heavily upon the aforementioned authors, particularly Țūsì and Shīrāzī.

The first chapter discusses salient features within the Hellenistic tradition that informed scientific production within Islam, thereby highlighting the vital importance of Aristotle (d. 322 BC) and Ptolemy to this activity. A survey of the planetary models produced by Shīrāzī, Țūsì, and al-'Urḍi forms the bulk of the second chapter, which also includes the study of key features of Aristotelian cosmology (e.g., Earth's centrality and immobility) as received and reexamined by the aforementioned scientists. The third and final chapter discusses the legacy of this school of scientific research within the Islamic world (and in Europe) in subsequent eras. Here, viewing the developments of theoretical astronomy within the framework offered by Thomas Kuhn (d. 1996), Gamini notes that the practitioners of this tradi-

1 The names of Persian-speaking scientists, such as Shīrāzī and Ṭūsī, have been rendered here in their Persian forms, that is to say, without the Arabic definite article "al-." 
tion ultimately could not free themselves from the confines of a Ptolemaic scheme for the universe and thus failed to truly transform their field. The author argues convincingly, however, that if the same criteria were applied to Copernicus (a figure often viewed as a scientific revolutionary), he too would fall short of this valuation.

The equant, a key feature of Ptolemy's astronomy, was a central focus of much of hay'a research, as various scientists attempted to grapple with a mathematical formulation that they viewed as physically untenable. In a review article published in the spring 2014 edition of the journal Irān va Islām, Gamini offers a compelling and somewhat novel view of how hay'a scientists conceptualized the equant. ${ }^{2} \mathrm{Al}-$ though included in Enamel Circles, this discussion appears only briefly as a footnote (83, n. 105). Another interesting discussion, entirely pretermitted, is of a rather interesting episode in Shīrāzī's work, in which he vociferously defends a patently flawed model for the superior planets before realizing his mistake and then, rather awkwardly, trying to cover his tracks in his later works. This flawed model, which was first discovered and published by Gamini himself, ${ }^{3}$ is noteworthy for being traceable in a number of Shīrāzī's treatises, and thus offers a rather unique window into the model-building activity of the era's scientific luminaries, who were not immune to committing occasional blunders.

It should also be noted that the vast majority of the many astronomical works listed in Enamel Circles await the publication of their definitive versions. Moreover, the importance of Gamini's contribution in listing them and providing a preliminary evaluation cannot be overstated. Indeed, the only other work of comparable scholarship that seeks to provide a comparably comprehensive account of the model-building activity within hay'a is George Saliba's 1996 essay. ${ }^{4}$ Gamini's work, which is more extensive and contains a good deal of new material (particularly regarding Shīrāzī), is therefore a most welcome addition to the rather sparse literature on this important topic.

2 Amir Mohammad Gamini, "Ahmad-i Dallal: Islām, 'ilm, va chālish-i tārīkh [Ahmad Dallal, "Islam, Science, and the Challenge of History]," Irān va Isläm nos. 1-2 (1393): 165-88. Here, the author questions the common interpretation of the equant's physical significance to astronomers working in the Islamic world by noting that its salient feature, the non-uniform motion of the epicycle's center with respect to the deferent's center, does not require an a priori assumption regarding the motion of those parts of the deferent that are not co-incident with the epicycle's center.

3 Amir Mohammad Gamini, "Planetary Model of Quțb al-Dīn Shīrāzī for Superior Planets" (paper presented at the XXIII International Congress of History of Science and Technology, Budapest, July 28August 2, 2009).

4 George Saliba, "Arabic Planetary Theories after the Eleventh Century AD," in Encyclopedia of the History of Arabic Science, ed. Roshdi Rashed, vol 1: Astronomy- Theoretical and Applied (London: Routledge, 1996), 58-127. 